\title{
Environmental Sustainability of Some Cropping Systems in the Humid Tropics
}

\author{
Bello, W. B.
}

\begin{abstract}
One of the greatest challenges facing agriculture in the tropics is the need to develop viable cropping systems for the rained uplands that are capable of ensuring increased and sustained crop production with minimum degradation of the non- renewable soil resource base. Increased population has reduced the effectiveness of shifting cultivation and other Traditional systems for sustainable farming and this gave way to improved practices. Cropping systems, therefore aimed at maintaining soil fertility with reduced effects on the environment. The main cropping systems in the humid are influenced by climatic situation and the type of crop grown, which mainly depend on crop diversification. Results from most findings reviewed in this paper had shown that there was no one size fits cropping system that can be use for sustainability of the humid environment but the best approach was the diversification of both traditional and modern cropping systems. The transition to systems which are both sustainable and sufficiently intense to support the increasing density of human population calls for attention on the cropping systems to be adopted. Hence, this paper focuses on exploring some cropping systems management for their sustainability in the humid tropics.
\end{abstract}

\section{Introduction}

Agricultural production has been identified as the backbone of African economy and this is why about two-third of the African people depend on it for their live-hoods. High dependent on agriculture stems from the fact that it affects the economic growth, social improvement, and 
trade within the continent and beyound. According to the World Bank's 1994 -95 population projections, the World's population will increase from 5.7 billion people in 1995 to 7 billions in 2020. This includes increases in China from 1.2 to about 1.5billion, South Asia from 1.3 to 1.9 billion, Africa from 0.7 to 1.2 billion. The rate of increase is likely to be highest in Africa despite the large population base in South Asia and China; there will inevitably be a substantial increase in these regions.

However, the International Food Policy Research Institute (IFPRI, 1997) has opined that between 1993 and 2020, that the global demand for Cereals is expected to increase by $41 \%$ while the developing Countries' demand for Cereals for feeding to livestock is expected to double, and demand for direct human consumption is expected to rise by $47 \%$, although the largest absolute increase will be greater for the latter. To this end, IFPRI (1999) further stated that developing countries will account for about $85 \%$ of the increase in global demand for Cereals and meat between 195 and 2020. Intensification on agricultural production from population pressure to meet demand for food will give rise to land degradation, desertification and global warming effect on the environment. Land degradation will be an important global concern because of its adverse impacts on agricultural production, food security and the environment.

Urbanization increases carbon emissions, whereas plants absorb carbon; Mannion (1997), observed that, with intensification, the agricultural area is decreasing in much of the developed World, with corresponding increases for example in the forested area with carbon sink. However, in the developing World, the agricultural area is tending to increase, tropical forest is being transformed into agricultural land, and agricultural land is being lost to urbanization. This development clearly reduces the vegetative carbon sink, as well as resulting in a loss of biodiversity and genetic resources.

The degradation of the land and urbanization in turns affect food security and livelihood of the poor farmers and the entire citizens of 
the continent. In some cases, the rate of land degradation is so high that drastic measures have to be made towards confronting the problems of nutrient depletion, deteriorating agricultural productivity so as to prevent undermine foundations of sustainable economic growth in Africa. (Julio and Carlos, 1999). The main concern is to ensure the sustainability of crop yields, a safe environment and profitability for the poor farmer with minimum use of input. Prasad (1997), opined that the ultimate goals or the end of sustainable agriculture are to develop farming systems that are productive and profitable, conserve the natural resource base, protect the environment and enhance health and safety in the long run.

However, the traditional systems that met the test of sustainability in the past have not been able to respond adequately to today's growth in the demand for agricultural commodities required by the current population pressures of human-kind, animals and rapidly declining resources of good and quality arable land and water resources. Base on this fact, Agro-forestry is been viewed as an Integrated nutrient management strategy on tropical soils for ecological necessity and economic reality. This paper, therefore, focuses on some Cropping systems management that have wide, universal, applicability and can help as a guide to the transition to sustainability in the humid tropics.

\section{Shifting Cultivation and its Limitation}

Shifting cultivation and fallowing have been the traditional method of maintaining soil fertility and replenishing nutrients in the tropics (Blackie, 1994a). However, due to increased population pressure in most areas, fallowing has disappeared from the system in some areas and is declining in others. Shortening of fallow cycles-without adequate replenishment of soil nutrients through the use of organic and inorganic inputs has caused yields to decline over time. (Ehuiet et al, 1994).

In the tropics, the "slash and burn" method has been widely used by small farmers as a means of land preparation and soil fertility maintenance practiced in different forms in different regions of the 
tropics. The so- called "Shifting cultivation or slash and burn agriculture" involves manually clearing, burning and cropping a relatively small area of land (0.5-1ha). For one or two years followed by a long period of natural fallow (e.g. 15-30 years). The land is usually allowed to return to forest or savanna vegetation to restore soil fertility (Mokwunye and Hammond, 1992).

In areas where the period of fallow has been shortened and cultivation has been extended for more than two years, crop yields generally decrease rapidly providing a constant pressure to clear new land (Ayodele, 1986). The detrimental effects of extensive clearing and burning of forest and grassland in the tropics are well known. For example, burning causes losses of most of the $\mathrm{N}, \mathrm{S}$ and $\mathrm{C}$ to the atmosphere. Large scale clearing accelerates soil erosion and surface sealing and crusting (Kooistra et al.; 1990; Vanderwatt and Valentin, 1992). Further more, subsequent cultivation may result in rapid deterioration of biological, chemical and physical properties of the soil.(Mokwunye and Hammond, 1992).

Published results on continuous cropping of kaolinite Alfisols and Ultisols in West Africa have shown a rapid decline in soil organic matter in the surface soil during the first few years following land clearing (Juo et al;; 1995). Continuous cultivation also causes significant decline in soil $\mathrm{Ph}$ and exchangeable $\mathrm{Ca}$ and $\mathrm{Mg}$ levels, which is more pronounced when acidifying fertilizers are used (Juo et al.; 1995a). The rate and magnitude of fertility decline are dependent on the length of fallow and cropping cycle, organic inputs, and the inherent fertility of the soil. In regions where increased land pressure has shortened the length of fallow below the critical level, the system has broken down because soil nutrient level became too low to support crop production (Juo and Manu, 1996).

The decline of crop yield under continuous cultivation has been attributed to factors such as acidification, soil compaction and loss of soil organic matter (Juo et al.; 1995a). Thus application of organic materials is needed not only to replenish soil nutrient but also to 
improve soil physical, chemical and biological properties. To a large extent, this may be achieved by managing agro-ecosystems such that nutrient sources are generated, recycled and maintained. One of such methods that readily come to mind is the cropping system.

\section{Cropping Systems}

This is defined as the pattern and spatial arrangement of crops on a piece of land. The idea behind cropping system is to improve soil fertility by maintaining the crop residue so as to improve the supply of organic material and which finally result into high increase in food production. A sustainable cropping system ensures biophysical sustainability by;-

- Restoring and protecting life support system by reducing contamination of air, water and soil by reducing or eliminating the use of biocides and fertilizer.

- The cropping pattern must enhance biotic diversity. This can occur by introduction of new species into the agro-ecosystem and must employ mixed cropping pattern for diversification of the ecosystems.

- The system must be able to conserve natural resources. This is in terms of inputs use on farm and must be with improved efficiency of use. It must reduce the dependency on fossil fuels and must be capable of conserving agricultural land.

- It must also satisfy the nutritional needs of the people involved in that environment (Lerner, 1991).

\section{Major Food Crops and Prevailing Cropping Systems in the Tropics}

The major crops of the Humid Africa includes, plantain, banana, rice and root crops (cassava, yam, sweet potato and cocoyam) in the humid zone, sorghum, maize and cowpea in the sub-humid zone and millet and cowpea in the semi-arid region (Subbarao, et al.;2000). 
Traditional cropping systems vary and have developed in response to prevailing soil and climatic conditions and socioeconomic and ethnological preference (Kang, 1986). Traditional farmers often plant more than one crop species in a small patch of cleared and burned land after several years of bush fallow. Intercropping, the practice of growing two or more crops simultaneously in the same field,is common through out the tropics. It is practiced in $80 \%$ of the cultivated area in West Africa (Subbarao, et al.; 2000). The multistory homestead gardens where more than three annual crop and vegetable species are mixed -planted with tree crops are common in the humid forest regions(Juo and Ezumah, 1992).

In terms of rainfall distribution and solar radiation during the growing season, large areas of the savannas are better suited for a wide range of rain-fed agriculture than the forest and semiarid zones. Most of the sorghum, millet, maize, cowpea, groundnut and yam are produced on the high base-status Alfisols in savanna zones of sub-Saharan Africa. In the humid region, dominated by the low base status and acid Ultisols and Oxisols, tree, shrub, and root crop based systems are proving to be more stable than food crop production systems as shown by the existence of highly successful tree crop plantations of rubber and oil palm (Kang, 1986).The cassava, plantain and rice based systems are prevalent in the humid region dominated by acid and low based status soils, whereas the maize, yam, sorghum and millet based systems are more common in the high based status soils in sub humid and savanna areas (Juo and Ezumah, 1992).

Six major food crop production systems have been identified in Subhumid Africa (Juo and Ezumah, 1992). In all traditional systems briefly mentioned i.e Cassava-cropping Rice, Yam, Maize, and Sorghum /Millet based cropping systems, bush fallow remains an integral part of the system though the length of fallow and cropping periods may vary depending upon soil condition and land use pressure. 
In Northern Zambia, maize yielded from $5,000 \mathrm{~kg} / \mathrm{ha}$ to about1, $000 \mathrm{~kg} / \mathrm{ha}$ during 17 years of cultivation with application of $190 \mathrm{kgN} / \mathrm{ha}$ on an oxisol (Woode, 1983). Continuous fertilizer use resulted in decreasing contents of soil organic matter (from 59-32t/ha) and exchangeable $\mathrm{Ma}$ and $\mathrm{K}$ and development of soil acidity. On Alfisols in Nigeria, soil $\mathrm{pH}$ declined from 6.2 to 5.1 during 10 years of continuous cropping with maize, sweet potato and cowpea, manual tillage and annual application of $160 \mathrm{~kg} \mathrm{~N} / \mathrm{ha}$ as urea, resulting in pronounced Mn toxicity for cowpea (Kang, 1993). Without fertilizer, $\mathrm{PH}$ declined by0.5units, while a slight $\mathrm{pH}$ increase was observed in the bush fallow treatment. Exchangeable $\mathrm{Ca}$ and $\mathrm{Mg}$ and organic $\mathrm{C}$ decline to about half their initial values during the 10years of the study. On this sandy soil, even the use of less acidifying $\mathrm{N}$ fertilizers (Urea and calcium ammonium nitrate).Resulted in rapid soil acidification after the initial 4years. Continuous cropping on Alfisol (Oxic Kandiustalf) in Nigeria with two maize crops per year and application of $120 \mathrm{kgN}$ as urea $(150 \mathrm{kgN}$ first three years) $26 \mathrm{kgP}$ and $30 \mathrm{~kg} \mathrm{~K}$ to each crop during 13years under no-tillage resulted in a steady decrease in $\mathrm{PH}$ from about 6.0 to 4.5 in the surface soil (0$15 \mathrm{~cm}$ ) when maize residue was not retuned (Juo et al.; 1995b). Soil organic $\mathrm{C}$ content decrease with continuous cropping during the first 8 years, then remained at $65 \%$ of the initial soil $\mathrm{C}$ content, with similar trends for exchangeable $\mathrm{Ca}, \mathrm{Mg}$ and effective cation exchange.

The above illustrations show that chemical fertilizer alone without organic inputs do not sustain soil productivity on the poorly buffered kaolinitic soils of sub-humid Africa. Furthermore, the use of lime to amend soil acidity is economically prohibitive to small holding farmers in the region due to scarcity of lime sources as well as high cost of transportation.

\section{Crop Diversification Principles and its Sustainability}

Recent ecological research on diversity indicates that diverse natural communities may be more productive than simple systems (Tilman, et al.; 1996), just as many agricultural studies have shown significant yield increase in diverse cropping systems compared to 
monocultures(Francis,1989). High-yielding in diverse cropping systems may result from a variety of mechanisms, such as more efficient use of resources (light, water, nutrients) or reduced pest damage, and there have been numerous experimental studies examining these mechanisms.

The mechanisms that result in greater productivity in diverse grass land systems are less well understood, but reduced nitrate losses from diverse systems suggest that increased nitrogen use efficiency may be one important mechanism (Tilman et al.; 1996).

Ecological studies suggest that more diverse plant communities with more diverse plant communities are more resistant to disturbance and more resilient in the face of environmental perturbations like drought. That is, the productivity of diverse communities appears to decline less during a drought and to return more quickly to pre-drought levels than is the case for species poor communities (Tilaman and Downing, 1994). A couple of studies have provided evidence of grater yield stability in diverse cropping systems ((Rao and Willey, 1980), suggesting that resistance to environmental perturbation may be higher in these systems.

Rao and Willey (1980), describe three mechanisms that might lead to yield stability in diverse cropping systems. First, when one crop performs poorly, because of drought or pest epidemic for example, the other crop(s) can compensate, using the space and resources made available such compensation is obviously not possible if the crops are grown separately. Secondly, the yield advantages of intercrops may be greater under stress conditions, and then yield stability is higher. Finally, where intercropping leads to reduced pest attack, as it often does (Power and Flecker, 1996), then grater yields stability may result.

The rate of over yielding increased with water stress, such that the relative differences in productivity between monoculture and polyculture became more accentuated as stress increased. These data are 
consistent with the idea that species richness buffers productivity under conditions of environmental variability and that diversity imparts resistance to perturbation (Tilma and Downing 1994).It means that the temporal and spatial diversification of cropping systems would lead to higher productivity and greater stability. These enable the agro-ecologist to conclude that species-rich natural ecosystems should be provided with models for the design of sustainable agricultural systems (Piper, 1992).

Yields declines are likely to be masked by increasing input levels, where such inputs are economically feasible. Thus, suggesting that yields from highly intensified production systems are likely to be unsustainable. Conservation of biological diversity on agricultural Landscapes also promotes biodiversity in agricultural systems themselves (Power, 1996 and Perfecto et al.; 1996). The above results show that sustainable agriculture and agro-ecological approaches have advantages over conventional agricultural systems and diversity is the main future of agro-forestry.

\section{The Major Improved Systems in the Humid Environment Agro-forestry}

This refers to all forms of land use system in which trees or woody perennials are deliberately planted on the same land management unit in association with livestock and/or annual crops with significant economic and ecological interactions between the woody and nonwoody components. Agro-forestry systems that interplant tree legumes with annual cereals can be effective in soil nutrient cycling and enhancement. It is a measure for checking extensive environmental degradation in sub-Saharan Africa (McNamara, 1990 and Okigbo, 1989).

The potential of these agro-forestry systems for Sub-Saharan West Africa has been highlighted by Kang (1990) as;(a) retrieval of nutrients from below the rooting zone of annual crops, (b) reduction of nutrient losses from leaching, runoff and erosion, and legumes trees increase the supply of nutrients within the rooting zone of annual 
crops through input of $\mathrm{N}$ by biological nitrogen fixation. In this context we shall focus on the agro-forestry systems of alley cropping and multistory homestead gardens in the sub-humid and humid zones.

\section{Alley cropping}

The traditional cropping and bush fallow land rotation systems relies on trees and shrubs for nutrient recycling and soil fertility regeneration. In an effort to improve this system and allow continuous crop production on the erosive but high base-Alfisols in the humid and sub-humid region of West Africa, researchers at the International institute of Tropical Agriculture (IITA) in Nigeria have developed the' alley cropping' system. In this system, food crops are grown in the 3 to4meters wide alleys along the contour formed by hedge-rows of planted, fast growing, leguminous shrubs and trees, like Leucaea (Leucaena leucocephala). The hedgerows are periodically pruned during the cropping season to prevent shading. Pruning materials are used as mulch and green manure for the associated food crops (Kang et al.; 1981).The woody portion of the pruning can also be used as fuel wood or sticks for yams. Leaves may also be used as folder during the dry season. Trees and shrubs with their deep root system planted along contours on sloping land not only are able to recycle soil nutrients, but also minimize water runoff and soil erosion (Juo et al,1994).

Kang et al; (1991) reported that the five tree legume species, namely, Cassia siamea, Leucaena leucocephala, Calliandra calothyrus, Gliricidia sepium, and Flemingia macrophylla, grown in $4 \mathrm{~m}$ spaced hedgerows on Alfisol in Ibadan, Nigeria, can produce 21.3,7.4,6.1, 5.5 , and $5.7 \mathrm{t} / \mathrm{ha} / \mathrm{yr}$ of dry matter from pruning, respectively. The corresponding nitrogen yield by each species were 394,247,218,169, and $149 \mathrm{kgN}$ per ha year, respectively. A review of published data also indicated that on high base -status soils (Alfisols, Entisols, and Andisols), nutrients recycled in hedgerow pruning from several legumeshrubs ranged from 50 to $180 \mathrm{kgN}, 2$ to $10 \mathrm{kgP}, 10$ to $15 \mathrm{kgK}, 10$ to $60 \mathrm{kgkg} \mathrm{Ca}$, and 5 to $25 \mathrm{kgMg}$ per ha(Kang et al.; 1990). 
Result of seven years of observations indicated that on high based status soils, alley cropping with leucaena can contribute between 40 and $60 \mathrm{~kg} \mathrm{~N} / \mathrm{ha}$ to the companion maize crop and can be used as a low -input (nitrogen) soil fertility maintenance system for food crop production (Kang et al.; 1984). A long -term maize leucaena cropping experiment conducted on an Alfisol in Ibadan, Nigeria, showed that maize grain yields of 2 to $3 \mathrm{t} /$ ha could be sustained for 10years without fertilizer input. The average yield of the control was $500 \mathrm{~kg} / \mathrm{ha}$. For higher maize yields of 4 to $5 \mathrm{t} / \mathrm{ha}$ using improved cultivars, 45 to $90 \mathrm{~kg}$ $\mathrm{N}$ fertilizer per ha would be needed (Kang and Duguma, 1985). A long-term alley farming trial with leucaena carried out on low fertility sandy soil also shows that maize yields can be sustained at acceptable levels with and without $\mathrm{N}$ application (Attah-Krah 1990).

Another benefit is weed suppression in alley farming which appears to be due to shading, mulching or allelopathy or a combination of these factors. Woody species such as Gliricidia have been used successfully for reclaiming Imperata- infested lands (Wiersum and Dirdjosoemarto 1987). Akeno'ova and Atta-Krah (1986) also showed that uncut Gliricidia hedge rows are effective in controlling imperata. In line with this, Siaw et al (1991), also viewed no difference in weed biomass yield between alley farmed and control treatments.

It has also been confirmed that run-off and erosion is reduced by the physical barrier of the hedge rows, and also by the better physical condition of the soil under the hedgerows, resulting from higher faunal (earth worm) activity, which increase water infiltration (Kang and Ghuman 1991 and kang 1988).The hedgerows in alley farming apart from providing prunings for mulching, green manure and folder also have auxiliary uses as stakes and fire wood (Kang et al. 1990).

A beneficial effect of alley cropping on acid soils is that the use pruning, as leguminous green manure can reduce soluble and exchangeable $\mathrm{Al}$ in soil by forming less soluble organo-Al complexes (Hue and Amien, 1989). On an acidic oxisol from Burundi with a high degree of Al saturation, application of tree legume pruning and farm 
manure decreased the concentration of Alumnium in soil solution from $2.9 \mathrm{ppm}$ in the control to $0.75 \mathrm{ppm}$ in plots receiving $6 \mathrm{t} / \mathrm{ha}$ of calliandra pruning (Wong et al.; 1995). Green manures generated by the system, can also break up pest life cycles and suppress the emergence and growth of weeds. Recent experiments indicate that some of this suppressive effect is due to the enhancement of weed pathogens in green manure systems compared to conventional systems (Liebman and Davis, 2000). Transforming technologies like green manures thus act initially as input substitutions but significantly alter ecosystem function.

It can be concluded that alley farming benefits includes; soil conservation and weed suppression, higher yields and sustained crop production, the supply of folder, stakes and fuel wood, socioeconomic benefit of low inputs, and a viable farming system that allows continuous cropping and reduces deforestation. The system's sustainability nature draws attention towards adapting its technology for acid and low-base status soils. The main problem is the selection of suitable woody species that can do well in acid soils with poor nutrient supply.

Alley farming studies on acid and low base-status soils in eastern Nigeria have shown good promise with species like A. barterii and Flemingia macrophylla. Farmers at Mbaise in Imo state of Southeastern Nigeria, have already adopted the practice of alley farming by using Acioa on acid soils for a few generations (Kang et al.;1981).

\section{Multi-storey Home Stead Gardens}

Multi-storey homestead gardens may be environmentally the most ecologically viable farming system for the indigenous people in the humid tropics (Juo, 1989). It is characterized by complete internal recycling of nutrients and organic matter by exploiting ecological balance of plant species in association with livestock production to meet the human needs on a family farm. Homestead gardens comprise a diversity of crop, animal and off-farm enterprises which contribute to the income of the farming system. The area around the house or 
farmyard is normally planted to a wide assortment of crops that require no purchased inputs and only low management.

In advanced farms, the number of economic plant species may be 50 to 60 , such as 5 to 6 tall growing species, 5 to 6 medium height tree species, 5 to 6 bush or shrub species, 4 to 5 roots crops, and up to 30shade-tolerant, short or vine type annuals (Okigbo and Greenland, 1976; Okigbo, 1980 ).The basic external inputs to the system, such as labor, manure, night-soil, and household wastes, are provided by the farm household. Soil productivity is maintained and enhanced by recyling plant residues and manure, and by biological nitrogen fixation by annual and woody legumes. Soil erosion is minimized by maintaining continuous ground cover and good water infiltration (Juo, 1989).

In the forest regions of Africa, less sophisticated multi-storey homestead gardens are common in densely populated areas including southern Nigeria, Western Cameroon, and Eastern Congo (formerly Zaire).

\section{Conclusion}

In the simplest sense, sustainability is the ability of a production (cropping) system to produce a stable annual yield of the desired crop over a long period of time. The length of time acceptable as a measure of sustainability is undefined and could be set arbitrarily for each particular environment and set of socio economic Circumstances. The best approach to a sustainable cropping system in the humid is to combine old and new methods of nutrient management into ecologically sound and economically viable organic and inorganic sources of nutrients in a judicious and efficient way. Secondly sustainability can be achieved with the integrated nutrient cycling with synchrony between nutrient demand by crop and nutrient release in soil while minimizing losses through leaching, runoff, volatilization and immobilization. 
The major goals that need to be addressed by a sustainable cropping systems includes( a)Conservation and efficient use of water resources, (b) prevention of erosion and soil degradation, and (c) enhancement of nutrient cycling. If we examine sustainable approaches to meeting these goals, we will see that there is a common thread involving the management of soil organic matter. Recent experience and research have brought us to conclusion, shared by earlier generations that soil organic matter management is a key factor in achieving successful long term sustainability. Trees are traditionally part of African farming systems because of their organic matter generating ability; hence agro-forestry demands more attention for sustainability of our soils.

The biological merits of alley cropping make it an important conservation farming practice for small holders and resource-poor farmers. This system also exploits moisture and nutrients deep in the soil profile. It permits nutrient recycling, improves soil structure, provides good soil erosion control and reduces the need for chemical fertilizers. Other traditional and improved agro-forestry systems already exist in Africa, some of which includes the home gardens and taugya systems in the humid tropics.

Further research is needed to study the sustainable elements of these and other systems and to assess how to increase their stability and productivity. 


\section{References}

Attah-Krah, A.N. and Suberg,J.E. (1988). "Studies With Gliricidia Sepium For Crop/Livestock Production Systems In West Africa." In: Gliricidia Sepium for: Management and Improvement. Proceedings of workshop held at CATIE, Costa Rica. NFTA Special Publication 87-01,pp 31-43.

Blackies, M.J. (1994a). "Maize Productivity for the 21th Century: The African Challenges." Outlook Agric. 23:189-195.

Crosson, A. (1992)."'Meaning of a Sustainable System". Journal of Sustainable Agriculture. Vol5, No112, 1992. Pp43-44.

Ehui S.; Willians T. and Swallow B (1994). "Economic Factors and Policies Encouraging Environmentally Detrimental Land Use Practices in Sub-Sahara Africa." Invited Paper, Xxii International Economist, 22-29 August 1994. Horere

Juo, A.S.R. and Manu A. (1996). "Chemical Dynamics of Slash and Burn Agriculture," Ecosystems And Environment. 58: 49-60.

Kang, B.T. and Renolds, L. (1986). "Alley Farming in the Humid and SubHumid Tropics." Paper Presented at IITA Board of Trustees Meeting 12-15 April 1986. IITA, Ibadan, Nigeria.

Kang, B.T.; Gichuru, M.; Hulugalle, N. and Swift, M.J. (1991). "Soil Constraints for Sustainable Upland Crop Production in Humid and Subhumid West Africa. in: Soil Constraints On Sustainable Plant Production In The Tropics" Tropical Agriculture Research Centre, Tsukuba, Japan, Pp.101-112.

Kang, B.T. (1993). "Changes in Soil Chemical Properties and Crop Performance with Continuous Cropping on an Entisol in the Humid Tropics" Pp 297-305. In. Mulongoy and Mercks R. (Eds). Soil Organic Matter Dynamics And Sustainability Of Tropical Agriculture. John Wiley And Sons.

Learner, (1991). "The Principle of Sustainable Agricultural System" Journal of Sustainable Agriculture. Volume 8 No.112 1991. pp20-24.

Liebman, M. and Davis A.S. (2000). 'Integration of Soil, Crop and Weed Management In Low-External-Input Farming Systems' Weed Research 40, 27-47.

Mannion, A.M. (1997). "Agriculture and Land Transformation. Part 2." Present Trends and Future Prospects outlook on Agriculture 26.3.pp 151 to 158. CAB International, 
Mokunye, A.U. and Hammond L.L. (1999). "Myths and Science of Fertilizer Use in the Tropics." In La, R. and Sanchez P.A. Myths and science of soils of the tropics SSSA Special Publication No 29, Pp 121-134

Maidison W. Perfecto, I.; Rice, R.A.; Greenberg, R. and Vandervoort, M.E. (1996). 'Shade Coffee: A Disappearing Refuge for Biodiversity' Bioscience 46(8), 598-608.

Power, A.G. and Flecker, A.S. (1996). "The Role of Biodiversity in Tropical Managed Ecosystems," G.H. Orians, R. Dirzo and J.H. Cushman (Eds), Biodiversity and Ecosystem Processes in Tropical Forests New York, Springer- Verlag,

Pinstrup; Anderson, M. W.; P.; Pandya L.R.;and Rosegrant M.W.(1999) "The World Food Situation: Recent Development, Emerging Issues, and Long Term Prospects." IFPRI. Washington, December, 1997.

Pinstrup, M.W.(1999) "World Food Prospects Critical Issues for the Early Twenty-First Century." IFPRI, Washington. October, 1999.

Prasad, R.N. (1997). "Integrated Nutrient Management: Indian Perspective." FAO. IFFCO. International Seminar on IPNS for Sustainable Development, New Delhi, November 1997.

Rao, M.R. and Willey, R.W. (1980). "Evaluation of Yield Stability in Intercropping: Studies on Sorghum/ Pigeon pea," Experimental Agriculture 16, 105-116.

Siaw, D.E.K.A.; Kang, B.T. and Okali, D.U.U (1991). "Alley Cropping with Leucaena leucocephala" (Lam.) de Wit and Acioa barteri (Hook f.) Engl. Agroforestry Systems 14, 219-231.

Subbarrao, G.V.; Renard, C.R.; Payne, W.A.; and Bationo, A.B. (2000). "Long-term Effects of Tillage, P Fertilization and Crop Rotation on Pearl Millet/Cowpea Productivity in West Africa." Experimental Agriculture 36: 243-264.

Tilman, D. and Dowing, J.A. (1994).'Biodiversity and stability in grass Lands,' Nature (London ) 367, 363-365.

Tilman, D.; Wedin, D. and Knops, J. (1996). "Productivity and Sustainability Influence By Biodiversity in Grass Land Ecosystems," Nature 379720.

World Resources Institute. World Resources (1994-1995). New York: Oxford University Press. 